\title{
Distributional status of some bats from Venezuela
}

\author{
by José OCHOA G. ${ }^{1}$ and Carlos IBANEZ ${ }^{2}$ \\ ' Servicio Nacional de Fauna Silvestre (MARNR), \\ Apartado 184, Maracay, Aragua, Venezuela; \\ ${ }^{2}$ Estación Biológica de Doñana, Apartado 1056, Sevilla-12, Spain.
}

Nouvelles informations sur la distribution, au Vénézuela, de 11 espèces de chauvessouris et commentaires sur leur statut taxonomique.

With the publication of "Mammals of the Smithsonian Venezuelan Project » (Handley, 1976), the situation of bats in Venezuela was sufficiently understood. However there is still a lack of information on some rare species. A revision of the specimens in some collections provides additional data on distribution and taxonomy of 11 species deposited in the following institutions: Museo de la Estación Biológica de Rancho Grande (EBRG) and Museo del Instituto de Zoología Agrícola de la Universidad Central de Venezuela (MIZAUCV), both in Maracay; Museo de Historia Natural La Salle (MHNLS) and Museo Biológico de la Universidad Central de Venezuela (MBUCV), both in Caracas and Estación Biológica de Doñana (EBD), in Seville, Spain.

Measurements are in millimeters and correspond to adult specimens with fused phalangeal epiphyses. The total skull length and the condylobasal length do not include the incisives.

\section{ACCOUNTS OF SPECIES}

\section{Pteronotus personatus (Wagner)}

Specimens examined (3). - ANZOATEGUI : Mamo, $8^{\circ} 28^{\prime} \mathrm{N}, 63^{\circ} 6^{\prime} \mathrm{W}, 2$ \% 2 (MHNLS). Afure: Caño Arauquita, $7^{\circ} 20^{\prime} \mathrm{N}, 67^{\circ} 07^{\prime} \mathrm{W}, 1$ \& (MBUCV).

Smith (1972) and Handley (1976) report the occurrence of this species in El Manteco (Bolívar), northern Carabobo, Yaracuy and Sucre. These specimens are the first record of this species from the Llanos region. The two females from Mamo, taken on the eleventh and twelfth of May, were pregnant. External and cranial measurements of a specimen from Mamo are as follows : length of forearm, 44.7 ; total length of skull, 15.5 ; condylobasal length, 14.4 ; zygomatic breadth, 8.4; mastoid breadth, 8.8 ; interorbital breadth, 3.5 ; length of maxillary toothrow, 6.1; breadth across upper molars 5.6. These measurements coincide with those of the nominate subspecies (Smith, 1972).

Mımmalia, t. 49, $n^{\circ} 1,1985$. 


\section{Choeroniscus godmani (Thomas)}

Specimens examined (8). - A.rzoategui : Mamo, $8^{\circ} 28^{\prime} \mathrm{N}, 63^{\circ} 6^{\prime} \mathrm{W}, 5 q^{\circ}$ (MHNLS). APURE: Hato El Frío, $30 \mathrm{~km}$ W El Samán, $7^{\circ} 43^{\prime} \mathrm{N}, 68^{\circ} 54^{\prime} \mathrm{W}, 2 \delta^{\circ} \delta^{\circ}$ (EBD). MIRAlidA : Valle Río Guire, $12 \mathrm{~km} S$ Panaquire, $10^{\circ} 7^{\prime} \mathrm{N}, 66^{\circ} 14^{\prime} \mathrm{W}, 1$ \% (MIZAUCV).

Handley (1966 and 1976) reported this bat from Venezuela in Bolívar, Falcón, and the Distrito Federal. The specimens from Apure and Anzoátegui reported here extend the known range of this species to the Llanos region.

Table 1 groups the measurements of the specimens of Apure, Anzoategui and Miranda as well as those reported by Handley (1966 and 1976). These measure-

TABLE 1. - External and cranial measurements of the Venezuelan specimens of Choeroniscus godmani reported in this paper and by Handley (1966 and 1976). Data are $\bar{X}, N$, (range) and SD.

\begin{tabular}{lcc}
\hline & Males & Females \\
\hline Forearm length & 32.9 & 33.8 \\
& $6(31.1-35.2)$ & $17(32.4-35.2)$ \\
& 1.36 & 0.79 \\
Total length & 19.2 & 20.6 \\
of skull & $6(18.9-19.5)$ & $17(20.1-21.1)$ \\
& 0.20 & 0.30 \\
Mastoid breadth & 8.1 & 8.1 \\
& $2(8.0-8.2)$ & $7(7.8-8.4)$ \\
Length of & - & 0.29 \\
maxillary & 6.7 & 7.2 \\
toothrow & $6(6.5-6.9)$ & $17(6.9-7.5)$ \\
Breadth across & 0.17 & 0.17 \\
upper molars & 4.0 & 4.1 \\
& $0(3.9-4.2)$ & $17(3.9-4.5)$ \\
& 0.09 & 0.17
\end{tabular}

ments do not differ from those already known for this species and probably confirm the opinion of Jones and Carter (1976) who consider C. godmani as monotypic.

The smaller size of this species, revealed by the total length of the skull, differentiates it from the other species of the genus (20.1-21.2 versus 22.0-3):3 for females and 18.9-19.7 versus 21.2-23.0 for males). Moreover, Handley (1966) notes the presence of a notch on the postlateral palatal ridge. The Venezuelan specimens we examined also present this feature.

\section{Choeroniscus minor (Peters)}

Specimens examined (4). - Bolivar: $28 \mathrm{~km} \mathrm{E} \mathrm{El} \mathrm{Palmar,} \mathrm{Río} \mathrm{Grande,} 8^{\circ} 01^{\prime} \mathrm{N}$, $61^{\circ} 42^{\prime} \mathrm{W}, 1 \hat{o}^{\hat{\prime}}$ (EBRG). T. F. Amazonas: Base del Cerro Cucurito, Caño Yagua, $3^{\circ} 32^{\prime} \mathrm{N}$,

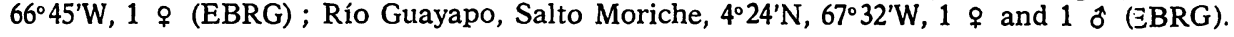

Only three specimens have been recorded from Venezuela in Bolivar (Handley, 1976), to which should probably be added those reported by Sanborn (1954) as Choeroniscus sp. and Phillips (1971) as C. intermedius respectively.

The female from Caño Yagua presents an extreme case of supernunerary molars, described by Ochoa and Fernández (1982), and the female from Ro Guayapo has four molars in both branches of the mandible and in the right naxilar. 
External and cranial measurements of the male from Bolivar, those of the male and female from Río Guayapo, followed (in parentheses) by a male reported by Handley (1976) are as follows: length of forearm, 35.0, 36.5, 34.4 (34.6) ; totai length of skull, 22.2, 22.7, 24.0 (23.0); mastoid breadth, 8.4, 8.2, 8.8 (-); length of maxillary toothrow, 7.6, 7.9, 8.1 (8.2); breadth across upper molars 4.2, 4.3, $4.6(-)$. With respect to the confusion surrounding the validity of $C$. intermedius and $C$. inca as species (Husson, 1962; Koopman, 1978; and Williams and Genoways, 1980), we follow Handley (personal comunication) in considering these two species as synonymous of $C$. minor. Koopman (1978) considers the measurement of the maxillary toothrow to be the determining factor in separating $C$. intermedius from $C$. minor and $C$. inca, the latter two considered synonyms by the same author. This measurement in 10 males and 26 females of $C$. intermedius from Trinidad (Genoways et al., 1973) covers a broad spectrum that includes the majority of those specimens assigned to $C$. minor and $C$. inca, as well as those reported here.

\section{Vampyrops brachycephalus Rouk and Carter}

Specimens examined (16). - ANzoategur: Mamo, $8^{\circ} 28^{\prime} \mathrm{N}, 63^{\circ} 06^{\prime} \mathrm{W}, 2 \% q$ and $1 \hat{\delta}$ (MHNLS). APURE: Hato El Frío, $30 \mathrm{~km}$ W El Samán, $7^{\circ} 43^{\prime} \mathrm{N}, 68^{\circ} 54^{\prime} \mathrm{W}, 4$ \% $\$$ (EBD). Bolivar : $8 \mathrm{~km} \mathrm{~S}, 5 \mathrm{~km}$ E El Mianteco, $7^{\circ} 19^{\prime} \mathrm{N}, 62^{\circ} 28^{\prime} \mathrm{W}, 1 \%$ (EBRG) ; Parque Loëfling, Puerto Ordaz, $8^{\circ} 19^{\prime} \mathrm{N}, 62^{\circ} 41^{\prime} \mathrm{W}, 3$ ¿ें ơ (MHNLS). MonaGas : Paso Real, Km 33 carretera Los Barrancos-Chaguaramas, $8^{\circ} 27^{\prime} \mathrm{N}, 62^{\circ} 43^{\prime} \mathrm{W}, 1 \%$ (MHNLS). T. F. DELTA AMACURo: Los Güires, $9^{\circ} 14^{\prime} \mathrm{N}, 61^{\circ} 53^{\prime} \mathrm{W}, 2 \%$ and $2 \delta^{\circ} \delta^{\circ}$ (EBRG).

Rouk and Carter (1972) and Handley and Ferris (1972) report this species from Sucre, Monagas, and Delta Amacuro in northern Venezuela. The specimens recorded here extend its distribution south and westwards.

As seen in Table 2, two populations could exist in Venezuela. One is smaller

TABLE 2. - External and cranial measurements of the specimens of Vampyrops brachycephalus. Data are $\overline{\mathrm{X}}, \mathrm{N}$, (range) and SD.

\begin{tabular}{|c|c|c|c|}
\hline & Apure & $\begin{array}{l}\text { Monagas, BolIvar } \\
\text { and Anzoategui }\end{array}$ & $\begin{array}{l}\text { T.F. Delta } \\
\text { Amacuro }\end{array}$ \\
\hline Forearm length & $\begin{array}{c}38.2 \\
4(37.0-40.0) \\
i .32\end{array}$ & $\begin{array}{c}39.6 \\
7(38.5-40.5) \\
0.60\end{array}$ & $\begin{array}{c}39.8 \\
4(38.8-42.1) \\
1.53\end{array}$ \\
\hline $\begin{array}{l}\text { Total length } \\
\text { of skull }\end{array}$ & $\begin{array}{c}21.0 \\
4(20.3-22.0) \\
0.72\end{array}$ & $\begin{array}{c}21.5 \\
7(21.1-22.0) \\
0.32\end{array}$ & $\begin{array}{c}21.6 \\
4(21.0-22.1) \\
0.46\end{array}$ \\
\hline $\begin{array}{l}\text { Zygomatic } \\
\text { breadth }\end{array}$ & $\begin{array}{c}12.2 \\
4(11.9-12.8) \\
0.42\end{array}$ & $\begin{array}{c}13.2 \\
7(12.6-13.7) \\
0.36\end{array}$ & $\begin{array}{c}13.0 \\
4(12.6-13.4) \\
0.33\end{array}$ \\
\hline $\begin{array}{l}\text { Interorbital } \\
\text { breadth }\end{array}$ & $\begin{array}{c}5.4 \\
4(5.0-5.6) \\
0.25\end{array}$ & $\begin{array}{c}5.5 \\
7(5.4-5.8) \\
0.16\end{array}$ & $\begin{array}{c}5.6 \\
3(5.6-5.7) \\
0.06\end{array}$ \\
\hline $\begin{array}{l}\text { Mastoid } \\
\text { breadth }\end{array}$ & $\begin{array}{c}10.7 \\
4(10.3-11.0) \\
0.35\end{array}$ & $\begin{array}{c}10.9 \\
6(10.6-11.2) \\
0.25\end{array}$ & $4(10.7-11.2)$ \\
\hline $\begin{array}{l}\text { Length of } \\
\text { maxillary } \\
\text { toothrow }\end{array}$ & $\begin{array}{c}7.5 \\
4(7.2-7.8) \\
0.25\end{array}$ & $\begin{array}{c}7.8 \\
7(7.6-8.0) \\
0.17\end{array}$ & $\begin{array}{c}7.7 \\
4(7.6-7.9) \\
0.15\end{array}$ \\
\hline $\begin{array}{l}\text { Breadth across } \\
\text { upper molars }\end{array}$ & $\begin{array}{c}8.9 \\
4(8.5-9.3) \\
0.34\end{array}$ & $7\left(\begin{array}{c}9.4 \\
0.1-9.6) \\
0.24\end{array}\right.$ & $4\left(\begin{array}{c}9.4 \\
0.2-9.6)\end{array}\right.$ \\
\hline
\end{tabular}


in size and is represented by the specimens from Apure, whose measurements coincide with those given for specimens from Loreto and Pasco in Perú, Colombia and Brazil (Rouk and Carter, 1972; Handley and Ferris, 1972). The specimens reported here from Monagas, Anzoátegui, Bolívar and Delta Amacuro show measurements which coincide with those reported by the above authors for specimens from northeastern Venezuela and Guyana and would belong to the other, eastern population. These measurements also resemble those of specimens from Huánuco, Peru, the locality type for this species.

This suggests that a population of smaller sized specimens separates the Huánuco population from the northeastern one of Venezuela and Guyana. In this case, the specimens from Huánuco would correspond to the nominate race and are probably restricted to higher altitude zones. Those from Loreto and Pasco in Peru, Colombia, Brazil and Apure in Venezuela would be assigned to $V$. b. latus, whose locality type would be Pasco in Peru. Those from northeastern Venezuela and Guyana would be represented $V$. b. saccharus, whose locality type is Sucre, Venezuela. However, the existence of a clinal variation of increase in size from the west to the east is also possible and only a revision of a greater number of specimens would permit this particular assessment of the data. The measurements of the specimens from Suriname given by Williams and Genoways (1980) could indicate this variation as these specimens are even larger than those from northeastern Venezuela and Guyana.

\section{Mesophylla macconelli Thomas}

Specimen examined (1). - Monagas : Río Uracoa, $13 \mathrm{~km}$ SW Chaguaramas, $8^{\circ} 38^{\prime} \mathrm{N}$, $62^{\circ} 53^{\prime} \mathrm{W}, 1$ ơ (MHNLS).

This species has only been collected in Venezuela in the humid forests of Barinas, Apure, Bolívar and T.F. Amazonas (Handley, 1976). This specimen is the first record from the Llanos region as well as being the first from a dry tropical forest, as classified by Ewel et al. (1976). The external and cranial measurements coincide with those published by Goodwin and Greenhall (1962) for the nominate race : length of forearm, 29.9; total length of skull, 17.5 ; condylobasal length, 15.8 ; zygomatic breadth, 10.3 ; mastoid breadth, 9.1 ; interorbital breadth, 4.4 ; length of maxillary toothrow, 6.1 ; breath across upper molars, 7.0. This locality record of the specimen is the nearest to the locality type of $M$. $m$. flavescens on the island of Trinidad (Goodwin and Greenhall, 1962).

\section{Thyroptera discifera (Lichtenstein and Peters)}

Specimen examined (1). - ARAgua: Edificio Estación Biológica de Rancho Grande, $1100 \mathrm{~m}, 10^{\circ} 21^{\prime} \mathrm{N}, 67^{\circ} 43^{\prime} \mathrm{W}, 1$ ơ (EBRG).

Puerto Cabello in Carabobo and San Julián in the Distrito Federal have been the only localities recorded for this species in Venezuela (Wilson, 1976). The most recent specimen was taken in 1900 (Robinson and Lyon, 1901). External and cranial measurements of the specimen from Aragua are: length of forearm, 32.1; total length of skull, 14.1 ; condylobasal length, 13.0 ; mastoid breadth, 6.7 ; interorbital breadth, 2.5 ; length of maxillary toothrow, 5.6 ; breadth across upper 
molars, 4.7. The specimen shows a chestnut brown dorsal and ventral coloring, which coincides with the color described by Wilson (1976) for specimens of the subspecies $T$. d. discifera. However, its size resembles that of the holotype of $T$. d. abdita (Wilson, 1976), which was separated from the nominate race solely for its size and on the basis of one female specimen, the only available adult as the paratypes were inmature. For these reasons, and spite of the distance between the Central and South American populations (Wilson, 1976), we recommend the reassessment of abdita as a subspecies, particularly as compared with a specimen from Suriname, whose measurements, given by Genoways et al. (1981) are very similar to those of the holotype of this subspecies.

\section{Molossops greenhalli (Goodwin)}

Specimens examined (5). - ARagua: El Limón, Maracay, $10^{\circ} 19^{\prime} \mathrm{N}, 67^{\circ} 37^{\prime} \mathrm{W}, 2$ q 9 (MIZAUCV). CARABOBO: Las Quiguas, San Esteban, $10^{\circ} 26^{\prime} \mathrm{N}, 68^{\circ} 00^{\prime} \mathrm{W}, 2$ \% $($ MHNLS). DISTRITo FEDERAL : Caracas, $10^{\circ} 29^{\prime} \mathrm{N}, 76^{\circ} 53^{\prime} \mathrm{W}, 1 \delta^{\circ}$ (MHNLS).

The only previous records of this species in Venezuela are two male specimens from Caracas, Distrito Federal (Linares and Kiblisky, 1969) and El Manaco, Bolfvar (Handley, 1976). External and cranial measurements of the specimens from El Limón followed of that from Caracas are as follows : length of forearm, 34.7, 32.7, 34.9 ; total length of skull, $16.5,16.6,17.1$; condylobasal length, $-, 15.7,16.4$; zygomatic breadth, $11.4,11.5,12.0$; mastoid breadth, 10.7, 11.1, 11.5; interorbital breadth, 4.1, 4.2, 4.2 ; length of maxillary toothrow, 6.3, 6.2, 6.6; breadth across upper molars 7.4, 7.7, 8.0. The cranial features of the new specimens coincide with those described by Goodwin (1958) for $M$. greenhalli. The outstanding features include a rounder, flatter braincase, an underdeveloped sagital crest, and a relatively narrower and higher rostrum. The dorsal coloration is reddish-brown with a whitish hair base at the neck and shoulders. The remaining dorsal hairs are of a uniform color. The underparts are paler than the back and a little darker on te flanks than at the center, without contrasting as much as in $M$. planirostris. The underparts have evencolored hairs with the exception of three specimens that show a whitish hair base at the throat. Williams and Genoways (1980) establish a difference between $M$. greenhalli and $M$. planirostris based upon the white dorsal hair base present in the former. However, specimens of $M$. planirostris from southern Venezuela share this feature even though their underparts show the typical coloring of their species. Moreover, the dorsal hair base of the specimen reported by Linares and Kiblisky (1969) as $M$. greenhalli, although a little paler, is not whitish. It appears to us that the white dorsal hair base is not a determinig feature in the separation of the species.

\section{Molossops sp.}

Specimens examined (4). - CARABOBO: Las Quiguas, San Esteban, $10^{\circ} 61^{\prime} \mathrm{N}, 68^{\circ} 00^{\prime} \mathrm{W}$, $1 \delta^{\circ}$ (MHNLS). Distrito FEDERAL : Caracas, $10^{\circ} 29^{\prime} \mathrm{N}, 76^{\circ} 53^{\prime} \mathrm{W}, 1 \&$ (MIZAUCV). MIRANDA : Guatopo, $10^{\circ} 5^{\prime} \mathrm{N}, 69^{\circ} 25^{\prime} \mathrm{W}, 1 \%$ and $1{ }^{\circ}$ (MBUCV).

External and cranial measurements of these specimens are given respectively as follows : length of forearm, 35.0, 35.0, - , 35.0; total length of skull, 17.5, 16.6, 
18.3, 16.6 ; condylobasal length, 17.0, 15.8, 17.8, 15.9 ; zygomatic breadth, 12.0, 11.8, -, 11.5 ; mastoid breadth, $12.3,11.3, \ldots, 11.4$; interorbital breadth, $4.3,4.5,4.9,4.4$; length of maxillary toothrow, 6.8, 6.5, 7.2, 6.6; breadth across upper molars, 7.6, $7.9,8.1,8.0$. Features of the four specimens coincide with Cynomops. The pelage, whith the exception of the male from Miranda whose skull was the only piece studied, shows some variations : in the male from Carabobo it is longer and silkier, and the central band down the length of underparts is of a yellowish color and paler than in the females. The three have reddish-brown dorsal hair. The hair base at the neck is whitish in the male from Carabobo and in the female from Miranda, the first has whitish shoulders whitish too. In te other female it is only a paler shade without being white.

A comparison with $M$. greenhalli shows that they coincide in size and differ in coloration. Their rostrum is also wider and lower and the edges of the nasal orifices do not project out as much. The braincase of Molossops $s p$. is less bulky and more angular with an even less distinct sagital crest. The lower ridge of the ocular orbit is flat and not angular as in the specimens of $M$. greenhalli examined.

As compared with specimens of $M$. planirostris from southern Venezuela, the recent specimens are somewhat darker and larger. Its lower orbital ridge is flat and not angular as in specimens of $M$. planirostris. The other cranial features are similar. This species has only been recorded in Apure, Guárico, Monagas, Bolívar and T.F. Amazonas in Venezuela (Handley, 1976 and August and Baker, 1982).

Handley (1976) considers M. paranus as a valid species and reports it from Bolívar and Yaracuy in Venezuela. Koopman (1978) and Freeman (1981) consider it to be a subspecies of $M$. planirostris. The specimens we examined differ from the description of $M$. paranus (Thomas, 1901). Their dorsal pelage has no blackish tones and the distance between the lacrymal ridges is greater than half the basal distance, although it is doubtful that this is a valid feature (Vizotto and Taddei, 1976) because of the great variation found in a population of M. planirostris in Brazil.

With respect to the foregoing, the specimens described here more closely approach the group planirostris and probably coincide with the denomination paranus since the original description is somewhat deficient (possibly owing to a deterioration in color of the specimens preserved in alcohol). In any case, the definitive denomination should be subject to a further revision of this group.

\section{Neoplatymops mattogrosensis (Vieira)}

\section{Specimens examined (3). - ANZontegui: Mamo, $8^{\circ} 28^{\prime} \mathrm{N}, 63^{\circ} 06^{\prime} \mathrm{W}, 3$ o o $\sigma^{\circ}$ (MHNLS).}

This species was previously known in Venezuela only southeast of Apure, Bolivar and T.F. Amazonas (Peterson, 1965 and Handley, 1976). The specimens from Anzoátegui represent the northernmost locality record for its area of distribution. External and cranial measurements of a specimen from Mamo are: length of forearm, 29.1; total length of skull, 14.6; condylobasal length, 14.1 ; zygomatic breadth, 9.8 ; mastoid breadth, 9.8 ; interorbital breadth, 3.5 ; length of maxillary toothrow, 5.8 ; breadth across upper molars, 6.3. 


\section{Eumops dabbenei Thomas}

Specimens examined (2). - ARAgua : Edificio Estación Biológica de Rancho Grande, $1100 \mathrm{~m}, 10^{\circ} 21^{\prime} \mathrm{N}, 67^{\circ} 43^{\prime} \mathrm{W}, 2$ \% $\%$ (EBRG).

Only three localities are recorded for this species in Venezuela: two from the Llanos region (Ibañez, 1979 and August and Baker, 1982) and one in Yaracuy (Handley, 1976), all three situated at an altitude of less than $100 \mathrm{~m}$ and within the dry tropical forest life zone, according to Ewel et al. (1976). The specimens examined here represent the first record of Eumops dabbenei from the Cordillera de la Costa in Venezuela, at an altitude of $1100 \mathrm{~m}$ in a premontane very humid forest life zone. External and cranial measurements of a specimen from Rancho Grande are as follows: length of forearm, 76.8 ; total length of skull, 31.9 ; condylobasal length, 29.6 ; zygomatic breadth, 19.9 ; interorbital breadth, 6.1 ; length of maxillary toothrow, 13.2 ; breadth across upper molars, 13.7 .

\section{Promops centralis Thomas}

Specimens examined (3). - Distrito FEDERAL: Caracas, $10^{\circ} 29^{\prime} \mathrm{N}, 76^{\circ} 53^{\prime} \mathrm{W}, 2$ ot ${ }^{\circ}$ (MHNLS). MONAGAS: Puente Morichal Largo, $8^{\circ} 48^{\prime} \mathrm{N}, 63^{\circ} 12^{\prime} \mathrm{W}, 1 \hat{\sigma}^{\circ}$ (MHNLS).

There have been only three specimens from Venezuela reported, one from Rancho Grande, Aragua (Tate, 1947), one from Caracas D.F. (Ojasti and Linares, 1971), the other from Bolivar (Handley, 1976). External and cranial measurements of the specimen from Monagas followed by the other from Caracas are : length of forearm, 52.5, 54.0; total length of skull, 20.7, 21.6; condylobasal length, 18.8, 20.5 ; zygomatic breadth, 12.6, 13.3 ; mastoid breadth, 11.6, 12.2 ; interorbital breath, $3.8,4.5$; length of maxillary toothrow, $7.7,8.5$; breadth across upper molars, 9.0, 9.9. These measurements coincide with those of the nominate race assigned to the specimens from northern South America by Ojasti and Linares (1971), Goodwin and Greenhall (1962), and Genoways and Williams (1979).

\section{ACKNOWLEDGEMENTS}

The authors thank the following persons: A. Fernández, A. Musso, and R. Pérez, curators of MIZAUCV, MHNLS, and MBUCV, respectively, C. Handley, for the information on the specimens deposited in the collections of the United States National Museum (USNM), including the measurements of Choeroniscus godmani and C. minor, corresponding to "Smithsonian Venezuelan Project" and S. Anderson, who allowed us to review the specimens of the American Museum of Natural History (AMNH). A part of this study was supported by the Instituto de Cooperacion Iberoamericana, Spain.

\section{SUMMARY}

We present new information on the distribution of 11 bat species in Venezuela and comment on their taxonomic status. 


\section{BIBLIOGRAPHY}

August, P.V., and R.J. BAKER, 1982. - Observations on the reproductive ecology of some Neotropical bats. Mammalia, 46: 177-181.

Ewel, J.J., A. MAdriz and J.A. Tosi, 1976. - Zonas de vida de Venezuela. 2nd ed. Ministerio de Agricultura y Cría, Caracas, 265 p.

Freeman, P.W., 1980. - A multivariate study of the family Molossidae (Mammalia, Chiroptera): morphology, ecology, evolution. Fieldiana Zool., n. s., 7: 1-173.

Genoways, H.H., R.J. BAKER and W.B. WyatT, 1973. - Nongeographic variation in the long-nosed bat, Choeroniscus intermedius. Bull. Southern California Acad. Sci., 72: 106-107.

Genoways, H.H., and S.L. Williams, 1979. - Records of bats (Mammalia : Chiroptera) from Suriname. Ann. Carnegie Mus., 48: 323-335.

Genoways, H.H., S.L. Williams and J.A. Groen. 1981. - Results of the Alcoa FoundationSuriname expeditions. V. Noteworthy records of Surinamese mammals. Ann. Carnegie Mus., 50: 319-322.

Goodwin, G.G., 1958. - Three new bats from Trinidad. Amer. Mus. Novitates, 1877 : 1-6.

Goodwin, G.G., and A.M. Greenhall, 1962. - Two new bats from Trinidad, with comments on the status of the genus Mesophylla. Amer. Mus. Novitates, 2080: 1-8.

HANDLEY, C.O., Jr., 1966. - Descriptions of new bats (Choeroniscus and Rhinophylla) from Colombia. Proc. Biol. Soc. Washington, 79: 83-98.

HANDLEY, C.O., Jr., 1976. - Mammals of the Smithsonian Venezuelan project. Brigham Young Univ. Sci. Bull., Biol. Ser., 20 (5) : 1-89.

HANDLEY, C.O., Jr., and K.F. FERRIS, 1972. - Descriptions of new bats of the genus Vampyrops. Proc. Biol. Soc. Washington, 84 : 519-524.

Husson, A.M., 1962. - The bats of Suriname. Zool. Verhandelingen, 58 : 1-282.

IbañEZ, C., 1979. - Nuevos datos sobre Eumops dabbenei Thomas, 1914 (Chiroptera, Molossidae). Doñana Acta Vertebrata, 6: 248-252.

JoNES, J.K., Jr., and D.C. CARTER, 1976. - Annotated checklist, with key to subfamilies and genera. P. 7-38, in: Biology of bats of the New World family Phyllostomatidae, part I (R.J. BAKER, J.K. JoNES, Jr. and D.C. CARTER, eds.), Spec. Publ. Mus., Texas Tech Tech Univ., 10: 1-218.

KoOPMAN, K.F., 1978. - Zoogeography of Peruvian bats with special emphasis on the role of the Andes. Amer. Mus. Novitates, 2651: 1-33.

LINARES, O.M., and P. KIBLISKY, 1969. - The karyotype and a new record of Molossops greenhalli from Venezuela. J. Mamm., 50 : 831-832.

OchoA G., J.R., and A. Fernandez, 1982. - Caso de hiperdoncia en Choeroniscus minor. Acta Cient. Venezolana, 33: 428-430.

OJASTI, J., and O.M. LiNARES, 1971. - Adiciones a la fauna de murciélagos de Venezuela con notas sobre las especies del género Diclidurus (Chiroptera). Acta Biol. Venezuelica, $7: 421-441$.

Peterson, R.L., 1965. - A review of the flat-headed bats of the family Molossidae from South America and Africa. Life Sci. Contrib., Roy. Ontario Mus., $65: 1-32$.

PhIll.rPs, C.J., 1971. - The dentition of Glossophagine bats: development, morphological characteristics, variation, pathology, and evolution. Misc. Publ. Mus. Nat. Hist., Univ. Kansas, $54: 1-138$.

RoBinson, W., and M.W. LyoN, 1901. - An annotated list of mammals collected in the vicinity of La Guaira, Venezuela. Proc. U. S. Nat. Mus., 24 : 135-162.

Rouk, C.S., and D.C. CARTER, 1972. - A new species of Vampyrops (Chiroptera : Phyllostomidae) from South America. Occas. Papers, Texas Tech. Univ., 1: 1.7.

SANBORN, C.C., 1954. - Bats from Chimantá-Tepuí, Venezuela, with remarks on Choero. niscus. Fieldiana, Zool., $34:$ 289-293. 
Smith, J.D., 1972. - Systematics of the chiropteran family Mormoopidae. Misc. Publ. Mus. Nat. Hist., Univ. Kansas, 56: 1-132.

TATE, G.H., 1947. - A list of mammals collected at Rancho Grande, in a montane cloud forest of northern Venezuela. Zoologica (New York), 32: 65-66.

Thomas, O., 1901. - On a collection of bats from Pará. Ann. Mag. Nat. Hist., ser. 7 (8) : 189-193.

VIZoTro, L.D., and V.A. TADDEI, 1976. - Notas sobre Molossops temminckii temminckii e Molossops planirostris (Chiroptera, Molossidae). Naturalia, 2: 47.54.

Williays, S.L., and H.H. Genoways, 1980. - Results of the Alcoa Foundation-Suriname Expeditions. II. Additional records on bats (Mammalia: Chiroptera) from Suriname. Ann. Carnegie Mus., 49: 213-216.

WILsoN; D.E., 1976. - The subspecies of Thyroptera discifera (Lichtenstein and Peters). Proc. Biol. Soc. Washington, 89 : 305-311. 
Brought to you by | Est Biologica de Donana (Est Biologica de Authenticated | 172.16.1.226

Download Date | 5/2/12 12:49 PM 